\title{
Tree Lilac (Syringa reticulata) Cultivars Tested As Street Trees: Second Report
}

\author{
Henry D. Gerhold
}

\begin{abstract}
Through the Municipal Tree Restoration Program, cooperators planted three tree lilac (Syringa reticulata) cultivars in 13 Pennsylvania and New York, U.S. communities for evaluation as street trees, comparing two in each community. Standardized measurements in years 1, 2, 3, 6, 9, and 12 revealed that 'Ivory Silk', 'Regent', and 'Summer Snow' grew well and remained healthy at all locations. Average heights of the cultivars in the 12 th year ranged from 4.8 to $5.1 \mathrm{~m}$ (15.8 to $16.8 \mathrm{ft})$. Differences in average height and crown width were small. In one community, the tallest cultivar, 'Ivory Silk', attained an average height of $6.4 \mathrm{~m}(21.1 \mathrm{ft})$ in the 12th year. 'Summer Snow' grew more slowly in height initially, and 'Regent' had narrower crowns. Foliage health ratings were somewhat lower than those of other species in some years, probably reflecting earlier yellowing of leaves in the autumn. If the tree lilac cultivars continue to grow at the same rate, they would not grow into overhead utility wires until the 18th year or later.
\end{abstract}

Key Words. 'Ivory Silk'; performance testing; 'Regent'; street trees; 'Summer Snow'; Syringa reticulate; tree lilac.

In 1987, the Municipal Tree Restoration Program (MTRP) began evaluating tree lilac (Syringa reticulata) cultivars and other species as street trees, mainly in Pennsylvania, U.S. MTRP encourages municipalities to improve their tree programs by demonstration plantings of free trees, and through research provides helpful information for selecting species and cultivars that are compatible with overhead utility wires. A previous report (Gerhold 1999) of initial results from the tree lilac tests confirmed that they grew slowly during the first 3 years and then somewhat faster but still at a moderate rate.

\section{MATERIALS AND METHODS}

\section{Plants and Experimental Design}

Cooperators planted the three tree lilac cultivars between 1987 and 2000 in 12 Pennsylvania communities and one in New York in United States Department of Agriculture plant hardiness zones 5 and 6 . Representatives of the communities chose the planting sites with the advice of utility foresters, service foresters in the Bureau of Forestry, or Penn State extension urban foresters.

Each test planting consisted of two cultivars typically planted alternately within four to 10 plots that contained 4 to 16 trees each, for a total of 50 trees in most of the communities. All test trees were planted along streets and under electric conductors. The utility company arranged for the removal of large trees in the plots that interfered with utility lines, thus making space for planting in some of the plots.

\section{Plant Materials}

The test trees came from several nurseries as balled-andburlapped stock, and the same nursery always supplied both cultivars for a community. Initial trunk calipers at $15 \mathrm{~cm}(6$ in) above grade ranged from 4.4 to $5.1 \mathrm{~cm}$ (1.76 to 2 in) and tree heights from 2.26 to $3.45 \mathrm{~m}$ (7.5 to $11.4 \mathrm{ft})$. The wide range in heights presumably could be explained by genetic differences among cultivars and diverse cultural differences among nurseries that supplied the trees. In most cases, 'Summer Snow' originally was shorter than its companion cultivar.

\section{Measurements and Analysis}

A trained cooperator inspected and measured the trees soon after planting, then annually during the first 3 years, and at 3-year intervals afterward. During September or October, a service forester or extension urban forester, using standardized procedures, measured tree height, trunk diameter, and crown width; classified the health of foliage, branches, and trunk separately; and rated maintenance needs and overall tree quality. Causes of injuries such as diseases, insects, drought, or mechanical damage were identified and recorded when possible.

An analysis of variance (using MINITAB's General Linear Model) of quantitative data collected in a given year calculated means and determined statistical differences between the cultivars at a particular location at the 5\% level of probability. Each test location in every year constituted a separate experiment with plots providing replication within a community. These results, along with comments provided by cooperators, were used to characterize performance of the cultivars.

\section{RESULTS AND DISCUSSION}

Eight of the tree lilac performance tests have been measured in the 12th or 13th year, and the others have attained the third, 
Table 1. Size and health ratings of tree lilac cultivars, planted as street trees, two cultivars in each community ${ }^{z}$.

\begin{tabular}{|c|c|c|c|c|c|c|c|}
\hline Cultivar & Location & Year & Diam. $(\mathrm{cm})$ & Ht. (m) & Width (m) & Foliage (1 to 5$)$ & Branches (1 to 5$)$ \\
\hline \multirow[t]{6}{*}{ 'Ivory Silk' vs. 'Regent' } & Waverly, NY & 13 & 10.23 & 4.37 & 2.53 & 4.1 & 4.1 \\
\hline & Patton & 12 & 10.54 & 4.58 & 3.11 & 4.0 & 4.5 \\
\hline & Shinglehouse & 12 & $12.02^{\mathrm{y}}$ & 5.80 & $3.51^{\mathrm{y}}$ & 3.6 & 4.8 \\
\hline & Dauphin & 9 & 10.98 & 4.41 & 3.50 & 4.7 & 4.9 \\
\hline & Jefferson & 6 & 6.57 & $3.57^{\mathrm{x}}$ & 2.35 & 3.8 & 4.6 \\
\hline & Wyomissing & 3 & 4.77 & 3.38 & 1.56 & 3.3 & 3.6 \\
\hline \multirow[t]{7}{*}{ 'Ivory Silk' vs. 'Summer Snow' } & Westfield & 13 & 10.98 & 6.44 & 4.03 & 4.4 & 4.6 \\
\hline & Athens & 12 & 8.64 & 4.48 & 2.47 & 4.1 & 4.6 \\
\hline & Corry & 12 & $9.30^{\mathrm{y}}$ & $5.25^{\mathrm{y}}$ & 3.69 & $3.3^{\mathrm{y}}$ & 4.0 \\
\hline & Hollidaysburg & 12 & 10.33 & 4.64 & 3.17 & 4.2 & 4.6 \\
\hline & Lebanon & 12 & 12.02 & 5.40 & 3.57 & 3.5 & 3.8 \\
\hline & Camp Hill & 9 & 9.60 & $4.88^{\mathrm{y}}$ & 3.57 & 4.9 & 4.9 \\
\hline & Laporte & 3 & $4.77^{\mathrm{y}}$ & $3.48^{\mathrm{y}}$ & $1.62^{x}$ & 4.9 & 4.9 \\
\hline \multirow[t]{6}{*}{ 'Regent' vs. 'Ivory Silk' } & Waverly, NY & 13 & 10.60 & 4.64 & 2.66 & 4.3 & 4.2 \\
\hline & Patton & 12 & 11.18 & 4.79 & 3.36 & 4.1 & 4.5 \\
\hline & Shinglehouse & 12 & $10.10^{\mathrm{x}}$ & 5.65 & $2.68^{x}$ & 3.8 & 4.7 \\
\hline & Dauphin & 9 & 11.60 & 4.61 & 3.39 & 4.9 & 5.0 \\
\hline & Jefferson & 6 & 6.80 & $4.00^{\mathrm{y}}$ & 2.04 & 4.0 & 4.6 \\
\hline & Wyomissing & 3 & 4.79 & 3.30 & 1.59 & 3.4 & 3.8 \\
\hline \multirow[t]{7}{*}{ 'Summer Snow' vs. 'Ivory Silk' } & Westfield & 13 & 10.03 & 5.37 & 4.09 & 4.4 & 4.6 \\
\hline & Athens & 12 & 9.28 & 4.76 & 2.56 & 4.1 & 4.6 \\
\hline & Corry & 12 & $7.46^{\mathrm{x}}$ & $4.58^{\mathrm{x}}$ & 3.69 & $2.9^{\mathrm{x}}$ & 4.0 \\
\hline & Hollidaysburg & 12 & 9.80 & 4.57 & 2.99 & 4.1 & 4.5 \\
\hline & Lebanon & 12 & 11.73 & 5.09 & 3.94 & 3.2 & 3.8 \\
\hline & Camp Hill & 9 & 9.34 & $4.30^{\mathrm{x}}$ & 3.29 & 4.9 & 5.0 \\
\hline & Laporte & 3 & $4.29^{\mathrm{x}}$ & $2.78^{\mathrm{x}}$ & $1.77^{\mathrm{y}}$ & 4.9 & 4.8 \\
\hline
\end{tabular}

${ }^{\mathrm{z}}$ Average trunk diameter, tree height, and crown width are in the most advanced year of measurement; foliage health and branch health ratings are averaged over all years: $1,2,3,6,9$, and 12 in most cases.

${ }^{\mathrm{y}}$ Significantly greater at $95 \%$ level than corresponding value of the paired cultivar.

${ }^{x}$ Significantly smaller at $95 \%$ level than corresponding value of the paired cultivar. Foliage and branch health ratings: $1=65 \%$ to $100 \%$ of leaves or branches exhibit injury, $2=45 \%$ to $60 \%, 3=25 \%$ to $40 \%, 4=5 \%$ to $20 \%, 5=$ less than $5 \%$.

sixth, or ninth year. 'Ivory Silk' is present in all 13 tests, 'Regent' is in six, and 'Summer Snow' in seven (Table 1). Survival ranged from $76 \%$ to $100 \%$ and averaged $90 \%$ or better in nine of the tests. In the 12th year, there were just a few significant differences in trunk diameter, height, and crown width and even fewer over the years in foliage health or branch health. Several community residents commented favorably about the trees, particularly about their creamy white flowers.

The rate of growth in height was similar for all three cultivars, except that 'Summer Snow' grew more slowly until about the sixth year and then grew at about the same rate as the other cultivars (Figure 1). Average heights of the cultivars in the 12 th year ranged from 4.8 to $5.1 \mathrm{~m}$ (15.8 to $16.8 \mathrm{ft})$. 'Ivory Silk' attained an average height in one community of $6.4 \mathrm{~m}(21.1 \mathrm{ft})$ in the 12th year. If the growth rate from year 9 to 12 continues, by the 18th year or later, the trees would attain a height of $\approx 7.6 \mathrm{~m}(25.1 \mathrm{ft})$ and could reach utility wires.

The crowns of 'Summer Snow' on average were slightly wider than those of 'Ivory Silk' and 'Regent' was narrower
(Figure 2) by $\approx 0.4 \mathrm{~m}(1.3 \mathrm{ft})$. 'Regent's divergence from the other two in crown width has been increasing since the sixth year.

No serious disease or insect problems were reported. Dieback of branch tips was observed in several localities, and

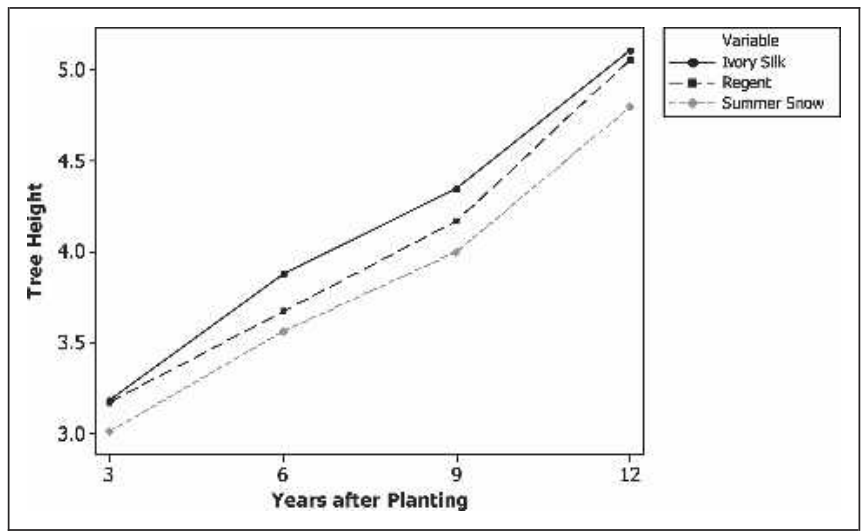

Figure 1. Average heights $(\mathrm{m})$ of cultivars 3 to 12 years after planting. 


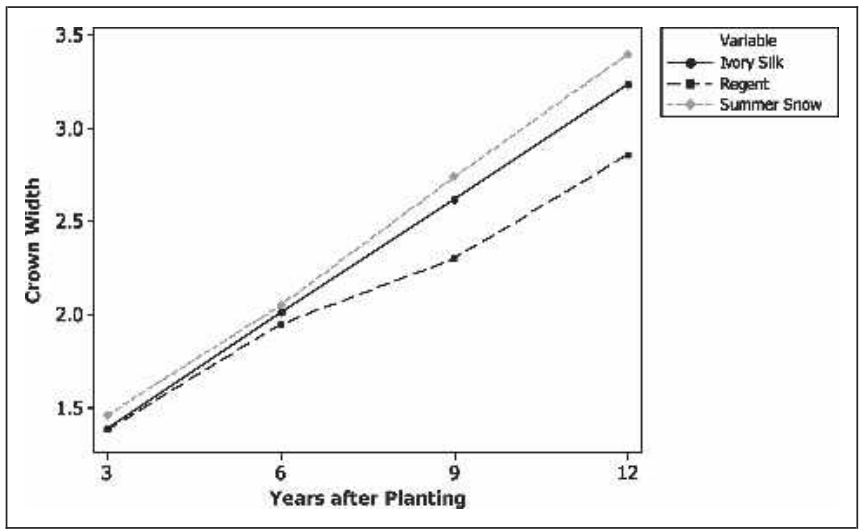

Figure 2. Average widths $(m)$ of cultivars 3 to 12 years after planting.

several observers attributed this to drought and other adverse site conditions. Trees growing in more spacious sites with better soils and soil moisture exhibited much better growth and healthier foliage. Leaves that were normal in size turned from dark or medium green to bright yellow earlier in the autumn than most other species, and this may have been a partial cause of lower foliage ratings.

\section{CONCLUSIONS}

'Ivory Silk', 'Regent', and 'Summer Snow' performed well as street trees, especially where site conditions were less stressful. Their moderate growth rate commends them where space is limited, and they are compatible with utility wires for 18 years or more. Minor health problems included dieback of branch tips and yellowing of foliage, especially after droughts.

Acknowledgments. Financial support for the Municipal Tree Restoration Program was provided by Allegheny Energy, Asplundh Tree Expert Co., Baltimore Gas \& Electric, Bartlett Tree Expert Co., Duquesne Light, Hazlett Tree Service, PECO Energy, FirstEnergy Corp., PPL Electric Utilities, and UGI Utilities. Service foresters of the Pennsylvania Bureau of Forestry and extension urban foresters of Penn State University assisted with community liaison and tree measurements.

\section{LITERATURE CITED}

Gerhold, H.D. 1999. Tree lilac cultivars tested as street trees: Initial results. Journal of Arboriculture 25:185-188.

\author{
Henry D. Gerhold \\ Professor of Forest Genetics \\ Pennsylvania State University \\ School of Forest Resources \\ 333 Forest Resources Building \\ University Park, PA 16802, U.S. \\ hdg@psu.edu
}

Résumé. Avec le Programme municipal de restauration des arbres, les coopérateurs ont planté 3 cultivars de lilas (Syringa reticulata) au sein de 13 municipalités des états de Pennsylvanie et de New York afin d'en faire l'évaluation comme arbre de rue, et ce en les comparant deux par deux par ville. Les mesures standardisées prises au cours des années $1,2,3,6,9$ et 12 ont permis de révéler que les cultivars 'Ivory Silk', 'Regent' et 'Summer Snow' poussaient bien et demeuraient en bonne santé sur les sites. La hauteur moyenne des cultivars à la $12^{\mathrm{e}}$ année variait de 4,8 à $5,1 \mathrm{~m}$. Les différences dans les hauteurs et les largeurs moyennes étaient faibles. Dans une municipalité, le plus grand des cultivars, soit 'Ivory Silk', a atteint une hauteur de 6,4 $\mathrm{m}$ à la douzième année. 'Summer Snow' poussait en hauteur plus lentement initialement et 'Regent' avait une cime plus étroite. Les degrés de santé du feuillage étaient quelques peu plus faibles que ceux des autres espèces certaines années, ce qui reflétait probablement un changement de couleur automnale plus hâtif des feuilles. Si les cultivars de lilas continuaient de pousser au même rythme, ils ne pourraient atteindre les fils électriques en surplomb avant la $18^{\mathrm{e}}$ année.

Zusammenfassung. Durch das kommunale Baumpflanzprogramm pflanzten die Teilnehmer 3 Fliedersträucher in 13 Gemeinden in Pennsylvannien und New York, um sie als Straßenbäume zu bewerten, wobei in jeder Kommune zwei verglichen wurden. Standardisierte Messungen in den Jahren 1, 2, 3, 6, 9 und 12 ergaben, dass „Ivory Silk“, „Regent“ und „Summer Snow“ gut wuchsen und an allen Standorten gesund blieben. Die durchschnittliche Höhe der Kultivare im 12. Jahr reichte von 4,8 $\mathrm{m}$ bis $5,1 \mathrm{~m}$. Die Unterschiede in der Höhe und Kronenbreite waren minimal. In einer Kommuneerreichte der größte Kultivar „Ivory Silk“ im 12. Jahr die durchschnittliche Höhe von 6,4 m. „Summer Snow“ ist in der Höhe anfangs langsamer gewachsen und „Regent“ hatte eine schmalere Krone. Die Gesundheit der Belaubung war etwas geringer als die von anderen Arten in einigen Jahren, und reflektiert dabei das frühe Vergilben der Blätter im Herbst. Wenn die Baumflieder mit der gleichen Rate weiter wachsen, würden sie nicht vor dem 18. Jahr in die Oberleitungen wachsen.

Resumen. A través del Programa Municipal de Árboles los cooperadores plantaron tres cultivares de árboles de lila (Syringa reticulata) en trece comunidades de Pennsylvania y New York para su evaluación como árboles urbanos, comparando dos en cada comunidad. Las mediciones estandarizadas en los años 1, 2, 3, 6, 9 y 12 revelaron que 'Ivory Silk', 'Regent', y 'Summer Snow' crecieron bien y permanecieron saludables en todas las localidades. Las alturas promedio de los cultivares en el año 12th varió de 4.8 a $5.1 \mathrm{~m}$ (15.8 a 16.8 pies). Las diferencias en altura promedio y diámetro de la copa fueron pequeñas. En una comunidad el cultivar más alto, 'Ivory Silk', alcanzó una altura promedio de 6.4 m (21.1 pies) en el año 12th. 'Summer Snow' creció más lentamente en altura inicialmente, y 'Regent' tuvo copas más estrechas. La salud del follaje fue un tanto más baja que otras especies en algunos años, probablemente reflejando amarillamiento temprano de las hojas en el otoño. Si los cultivares de lila continúan creciendo a la misma tasa, podrían no superar las líneas de servicios hasta el año 18th o posterior. 